\title{
DEVELOPMENT OF NUCLEAR ENERGY AND RADIATION TEXTBOOKS FOR ELEMENTARY, MIDDLE, AND HIGH SCHOOL STUDENTS
}

\author{
Eun Ok Han ${ }^{*}$ PhD, Jae Rok Kim* PhD, Mr. Yoon Seok Choi*, James Lochhead ${ }^{\dagger}$ \\ *Department of Education \& Research, Korea Academy of Nuclear Safety, Seoul 135-703, Korea \\ ${ }^{\dagger}$ Department of English Education, Pusan National University
}

Received June 18, 2015 / 1st Revised August 7, 2015 / Accepted for Publication August 13, 2015

To develop tailored elementary, middle, and high school textbooks suitable for understanding the nuclear energy and radiation, quantitative and qualitative research was carried out in parallel, which included nine steps to ensure the validity of content and structure. The elementary, middle, and high school students wanted to acquire information used in their daily lives, including the definition of nuclear energy and radiation, principles and status of nuclear power generation, and information about irradiated food, medical radiation, and radiation in life. In the evaluation of the effects of textbook contents according to the educational requirements of each school level, high suitability frequencies (>80\%) were shown for the human character, education goals, curriculum goals, evaluation method, and education time. At some levels, the high suitability frequencies $(>70 \%)$ were shown for the education grade, education type, and textbook type.

Keywords: Nuclear energy, Radiation, Textbook, School student, Education, Perception

\section{INTRODUCTION}

For the fluid diversity of use of radiation in the nuclear power generation, which is a major source of energy and improvements in health and welfare in South Korea, the knowledge and trust of the citizens is required [1, 2]. However, because average individuals do not have enough science and technology knowledge, they rely on emotional perceptions based on their experiences rather than rational judgments [3]. The perception of risk has characteristics of cognitive anchoring induced by strong and negative images, such as the Chernobyl and Fukushima nuclear power plant accidents and the consequences thereof. Thus, perception of risk in nuclear energy, related technologies, and nuclear facilities are affected greatly [4, 5]. After the Fukushi-

Corresponding author : Eun Ok Han, haneunok@gmail.com

Department of Education \& Research, Korea Academy of Nuclear Safety, Korean Federation of Science Societies, Yeoksam 1(il)-dong, Gangnam-gu, Seoul 135-703, South Korea ma nuclear power plant accident, the negative information about direct and indirect effects, such as the radiation contamination of marine products, radioactive concentration in atmosphere, and safe food for future generations, were often reported by the news media [6]; consequently, the negative perception of nuclear power generation and radiation has increased [7-11]. Furthermore, although the need for raising the ability to judge the media critically is increasing, no one can escape the influence of media in our information-based society [13]. It is very difficult for the average individual to make proper value judgments in a social environment where incorrect or hardly understandable information about nuclear power and radiation is disseminated through the media. For this reason, there are many issues surrounding the use of radiation and nuclear power in South Korea [12].

To address the gap existing between average citizens and experts, even though it is not due to a simple difference in knowledge, high quality information and ed- 
ucation are key components [14]. Education cannot be isolated from media in our information-based society, but can bring social changes [15]. Therefore, relevant education must be provided to ensure social acceptance and appropriate judgments of the values and risks of nuclear energy and radiation, which are important for future generations. In South Korea, students learn about nuclear power generation as well as radiation through minimal information in science textbooks; most students acquire concepts through teaching-learning activities between teachers and students. Therefore, if a science teacher has an inaccurate perception about nuclear energy and radiation, this may have an improper influence on students. Textbooks are not only the most common source of knowledge for students but also the most important teaching-learning materials, and essential tools for teachers. In school education, the influence of textbooks is absolute. The basic function of textbooks is to present knowledge to students in a manner and order that the students can comprehend and accept. Therefore, textbooks have a function in determining and controlling the direction and scope of teaching and learning [16]. However, at present, although there is serious social confusion about nuclear energy and radiation, no school subjects or teaching materials have been developed.

The most important and difficult task in developing curriculum is selecting the educational content [17]. The content must be that which is required by most students and most urgently needed. It must be able not only to attract the attention and interest of students but also to raise and satisfy their curiosity [18]. The contents must include the information necessary to solve problems and achieve students' goals. In the construction of curriculum, the psychological development of students, in addition to their demands and needs, must be taken into consideration; when there is a strong focus on students, the efficiency of education is increased [19]. However, fragmentary information provided by relevant organizations about nuclear energy and radiation does not provide the basis for informed value judgments by average individuals or students; instead, it provides knowledge from the perspective of experts. As a result, the social acceptance of nuclear energy and radiation use has not been adequately facilitated. Tyler et al. (1949) emphasized that various circumstances must be considered in selecting and organizing educational curriculum and activities [20].
Therefore, taking the circumstances of the present time and the situation of information receivers, this study aimed to develop textbooks about nuclear energy and radiation targeting elementary, middle, and high school students, the leaders of the next generation.

\section{METHODS}

In this study, to develop tailored elementary, middle, and high school textbooks suitable for understanding the nuclear energy and radiation, qualitative and quantitative research was carried out in parallel, which included nine steps to ensure the validity of content and structure.

\subsection{Step 1}

A discussion session regarding the status and educational direction of nuclear energy and radiation understanding was held with twelve people representing science teachers of each grade and experts of nuclear energy and radiation. At this meeting, it was determined that standardized nuclear energy and radiation education is necessary, and the methods of regular class and creative experience learning were selected as the appropriate educational formats. There were various opinions regarding the education medium and contents, and common opinions were reflected in the survey questionnaire.

\subsection{Step 2}

The format and contents of education on nuclear energy and radiation for students in South Korea and overseas were collected. Information was currently provided on a variety of methods, including the dispatching of instructors, information sharing on a websites, Questions and Answers, textbook publication, field study, and mentoring programs at various organizations (Korea Hydro \& Nuclear Power, Korea Nuclear Energy Foundation, Korea Institute of Nuclear Safety, Korea Atomic Energy Research Institute, Korea Academy of Nuclear Safety, Korean Association for Radiation Application, and Women in Nuclear Korea). The concepts, principles, and use of nuclear energy and radiation accounted for the largest proportion of the contents of the materials, and other information, such as effects on humans and safe management methods, were provided. 


\subsection{Step 3}

Student discussion sessions were held to construct the educational requirement draft that included the information that elementary, middle, and high school students wanted to know about nuclear energy and radiation. Approximately eight students were recommended by science teachers from the sixth grade of elementary school, third year of middle school, and third year of high school (the final year of each school level) and a discussion session was held separately for each level. Through the discussion sessions, objective and varied information on nuclear energy and radiation was provided; this was followed by an open discussion on the themes and contents that held interest for the students. After the discussion, students were asked to compose the themes and content for 13 class lessons to be learned in one semester, and the high frequency themes and contents themes were included on the previously mentioned survey questionnaire. Using the questionnaire, preliminary surveys were carried out at each school level to ensure the validity of content in the questionnaire.

\subsection{Step 4}

A partial revision was made to the preliminary survey questionnaire for 13 class lessons through consultation with science teachers and experts. When there were differences in the suggested content, precedence of the contents and themes of the students were taken over those of the teachers and experts.

\subsection{Step 5}

The educational requirements survey was conducted to select the tailored educational content. In elementary schools, 134 people participated: 57 sixth grade students (42.5\%), 32 elementary school science teachers (23.9\%), and 45 experts in the fields of nuclear energy and radiation (33.6\%). In middle schools, 126 people participated: 52 third-year students (41.3\%), 29 middle school teachers (23.0\%), and 45 experts in the fields of nuclear energy and radiation (35.7\%). In high schools, 131 people participated: 56 third-year students (42.7\%), 30 high school science teachers (22.9\%), and 45 experts in the fields of nuclear energy and radiation (34.4\%). For the selection of themes and contents of thirteen class lessons covering one semester, we attempted to reflect the opinions of students, science teachers, and experts. Using SPSS Windows 15.0, the frequencies and percentages of themes and contents were identified.

\subsection{Step 6}

The content and structure validity of the educational content result for nuclear energy and radiation understanding, developed in consultation with the nuclear energy and radiation experts, were reviewed; the statistical analysis results were confirmed.

\subsection{Step 7}

Twelve experts in the pertinent field addressed in each class lesson wrote the contents, which resulted in the preliminary textbooks. The authors were nuclear energy and radiation professors and experts in national regulatory organizations, research institutes, and universities. To match the contents to the grade levels, science teachers of the school levels edited the developed textbook contents.

\subsection{Step 8}

The textbooks were evaluated in two sets of simulated classes. First, the suitability of textbook contents for each class lesson, such as content and structure suitability, simplicity or difficulty, and amount of preliminary textbooks, was evaluated. The evaluation of the textbooks was held after conducting the first set of simulated classes, using the preliminary textbooks, for sixth grade elementary school students, second-year middle school students, and first-year high school students; these grades were deemed the appropriate place for the curriculum developed in Step 5. There were 95 textbook evaluators: 30 sixth grade elementary students (31.6\%), 34 second-year middle school students (35.7\%), and 31 first-year high school students (32.6\%). Based on the evaluation of content suitability for each lesson in the textbooks, the revision and supplementation process was conducted. Using the finalized textbooks, the second set of simulated classes was conducted for the analysis of educational effect. There were 143 evaluators of educational effect: 37 sixth grade elementary students, 33 second-year middle school students, and 73 first-year high school students. To ensure the objectivity of evaluation, different evaluators took part in the first and second rounds. For the analysis, SPSS Windows 15.0 was used to analyze the averages, standard deviations, frequencies, and percentages.

\subsection{Step 9}

The final draft of the textbooks was determined 
through consultation with the experts. Minimize errors of the instructor is required so performed by one expert lecture. This result does not represent the opinion of all elementary, middle, and high school students in Korea. Taba (1962) noted that the first step in educational curriculum development is connecting theory and practice, and it is followed by eight subordinate steps sequentially: diagnosis of requirements; setting a goal; selection of contents; organization of contents; selection of study experiences; organization of study activities; determination of evaluation targets, method, and measures; and verification of balance and sequence [21]. Taba's educational curriculum development steps were used in this study.

\section{RESULTS}

\subsection{Theme Suitability for Elementary School Students}

The themes of the 13 lessons had a high suitability frequency (>70\%). The lowest rating was $73.7 \%$ for "Which jobs are related to nuclear energy and radiation?” (Lesson 11). Theme suitability was measured by assigning one point to each suitable lesson; the overall suitability was rated as 11.18 by elementary school students, 10.10 by elementary school science teachers, and 10.97 by experts. This represents a high average suitability of 10.84 . Therefore, the themes were suitable for inclusion in the elementary school textbook (Table 1).

Table 1. Themes of Suitability for Elementary School Students.

\begin{tabular}{|c|c|c|c|c|c|c|}
\hline Lesson & Theme & & $\begin{array}{c}\text { Elementary } \\
\text { school students }\end{array}$ & $\begin{array}{c}\text { Elementary } \\
\text { school teachers }\end{array}$ & Experts & $\begin{array}{c}\text { Total } N \\
(\%)\end{array}$ \\
\hline 1 & Definition of nuclear energy and radiation & Suitable & $45(78.9)$ & $28(87.5)$ & $43(95.6)$ & 116(86.6) \\
\hline 2 & History of nuclear energy and radiation & Suitable & $47(82.5)$ & $16(50.0)$ & 39(88.6) & 102(76.7) \\
\hline 3 & Importance of nuclear energy and radiation & Suitable & $54(94.7)$ & $25(78.1)$ & $38(84.4)$ & 117(87.3) \\
\hline 4 & Risks of nuclear energy and radiation & Suitable & $54(94.7)$ & 31(96.9) & $36(80.0)$ & 121(90.3) \\
\hline 5 & Coping methods during an incident & Suitable & $55(96.5)$ & $30(93.8)$ & $35(77.8)$ & $120(89.6)$ \\
\hline 6 & Utilization of nuclear energy and radiation & Suitable & $47(82.5)$ & 29(90.6) & 44(97.8) & 120(89.6) \\
\hline 7 & Nuclear energy generation & Suitable & $47(82.5)$ & $17(53.1)$ & $37(82.2)$ & 101(75.4) \\
\hline 8 & Irradiation of food & Suitable & $46(80.7)$ & $20(62.5)$ & $34(75.6)$ & $100(74.6)$ \\
\hline 9 & Medical radiation & Suitable & $50(89.3)$ & $24(75.0)$ & $33(76.7)$ & $107(81.7)$ \\
\hline 10 & Radiation-related products in daily life & Suitable & $50(87.7)$ & $23(74.2)$ & $34(75.6)$ & $107(80.5)$ \\
\hline 11 & Nuclear energy and radiation related jobs & Suitable & $41(73.2)$ & $25(78.1)$ & $32(71.1)$ & 98(73.7) \\
\hline 12 & Energy in the future & Suitable & $53(93.0)$ & $29(90.6)$ & $44(97.8)$ & $126(94.0)$ \\
\hline 13 & Concept of Talk-Talk(a study review game) & Suitable & $47(82.5)$ & 26(81.3) & 40(90.9) & $113(85.0)$ \\
\hline \multirow{2}{*}{\multicolumn{2}{|c|}{ Theme suitability (average) }} & Suitable & 11.18 & 10.10 & 10.95 & 10.84 \\
\hline & & Unsuitable & 1.82 & 2.9 & 2.05 & 2.16 \\
\hline
\end{tabular}

* The themes of suitability were scored from 0 to 13 points.

Table 2. Themes of Suitability for Middle School Students.

\begin{tabular}{|c|c|c|c|c|c|c|}
\hline Lesson & Theme & & $\begin{array}{l}\text { Middle school } \\
\text { students }\end{array}$ & $\begin{array}{c}\text { Middle school } \\
\text { teachers }\end{array}$ & Experts & $\begin{array}{c}\text { Total N } \\
(\%)\end{array}$ \\
\hline 1 & Definition of nuclear energy & Suitable & $44(84.6)$ & $27(90.0)$ & $45(100.0)$ & 116(91.3) \\
\hline 2 & Nuclear energy technology & Suitable & $40(76.9)$ & $20(69.0)$ & $36(80.0)$ & $96(76.2)$ \\
\hline 3 & Current status of nuclear energy utilization & Suitable & $39(75.0)$ & 28(93.3) & 41(91.1) & 108(85.0) \\
\hline 4 & Definition of radiation & Suitable & $45(86.5)$ & 25(86.2) & 42(93.3) & 112(88.9) \\
\hline 5 & Risks of radiation & Suitable & $50(96.2)$ & $27(90.0)$ & 39(86.7) & 116(91.3) \\
\hline 6 & Use of radiation for food & Suitable & $35(67.3)$ & $17(65.4)$ & $40(88.9)$ & 92(74.8) \\
\hline 7 & Household products using radiation & Suitable & $40(76.9)$ & $24(80.0)$ & 39(88.6) & 103(81.7) \\
\hline 8 & Radiation in life & Suitable & $45(86.5)$ & 29(96.7) & 42(95.5) & 116(92.1) \\
\hline 9 & Nuclear bombs & Suitable & $37(71.2)$ & $20(66.7)$ & $30(71.4)$ & $87(70.2)$ \\
\hline 10 & Misunderstandings and truths about radiation & Suitable & $46(88.5)$ & $27(90.0)$ & $37(84.1)$ & $110(87.3)$ \\
\hline 11 & Progress in nuclear energy research & Suitable & $34(66.7)$ & $22(75.9)$ & $30(68.2)$ & $86(69.4)$ \\
\hline 12 & Pro-con debate about nuclear energy & Suitable & 25(49.0) & 19(65.5) & $34(77.3)$ & $78(62.9)$ \\
\hline 13 & Energy in the future & Suitable & $49(94.2)$ & 28(93.3) & $44(100.0)$ & 121(96.0) \\
\hline \multirow{2}{*}{\multicolumn{2}{|c|}{ Theme suitability (average) }} & Suitable & 10.14 & 10.65 & 11.29 & 10.66 \\
\hline & & Unsuitable & 2.86 & 2.35 & 1.71 & 2.34 \\
\hline
\end{tabular}

* The themes of suitability were scored from 0 to 13 points. 


\subsection{Theme Suitability for Middle School Students}

In 11 lessons out of 13, the theme suitability frequencies were high (>70\%). The lowest suitability rating was for "Pros and cons in the debate on nuclear energy” (Lesson 12) (62.9\%), but had a relatively high suitability rating by experts (77.3\%). "Progress in nuclear energy research” (Lesson 11), the second lowest suitability rating (69.4\%), had a rating of $75.9 \%$ by teachers. Theme suitability was measured by assigning one point to each suitable lesson; the overall suitability was rated at 10.14 by middle school students, 10.65 by middle school science teachers, and 11.29 by experts. This represents a high average suitability of 10.66 . Therefore, although a partial revision is required for Lessons 11 and 12, these themes were suitable for inclusion in the middle school textbook (Table 2).

Table 3. Themes of Suitability for High School Students.

\begin{tabular}{cllrrrr}
\hline Lesson & \multicolumn{1}{c}{ Theme } & High school & $\begin{array}{c}\text { High school } \\
\text { students }\end{array}$ & $\begin{array}{c}\text { teachers } \\
\text { Experts }\end{array}$ & $\begin{array}{c}\text { Total N } \\
\text { (\%) }\end{array}$ \\
\hline 1 & History of nuclear energy and radiation & Suitable & $39(69.6)$ & $27(90.0)$ & $40(88.9)$ & $106(80.9)$ \\
2 & Definition of nuclear energy and radiation & Suitable & $53(94.6)$ & $30(100.0)$ & $43(95.6)$ & $126(96.2)$ \\
3 & Misunderstandings and truths about radiation & Suitable & $47(85.5)$ & $25(86.2)$ & $40(88.9)$ & $112(86.8)$ \\
4 & Types of radiation & Suitable & $50(89.3)$ & $29(96.7)$ & $45(100.0)$ & $124(94.7)$ \\
5 & Nuclear power generation & Suitable & $44(78.6)$ & $27(90.0)$ & $44(97.8)$ & $115(87.8)$ \\
6 & Radiation utilization for food & Suitable & $41(73.2)$ & $24(80.0)$ & $40(88.9)$ & $105(80.2)$ \\
7 & Medical radiation & Suitable & $47(83.9)$ & $27(90.0)$ & $42(93.3)$ & $116(88.5)$ \\
8 & Industrial radiation & Suitable & $38(67.9)$ & $24(80.0)$ & $42(93.3)$ & $104(79.4)$ \\
9 & Radiation for research & Suitable & $40(71.4)$ & $21(72.4)$ & $40(88.9)$ & $101(77.7)$ \\
10 & Current domestic and overseas status related to radiation & Suitable & $43(76.8)$ & $27(90.0)$ & $39(86.7)$ & $109(83.2)$ \\
11 & Radiation incidents and contamination & Suitable & $51(91.1)$ & $29(96.7)$ & $36(80.0)$ & $116(88.5)$ \\
12 & Discussion (expert-centric) & Suitable & $31(55.4)$ & $28(93.3)$ & $40(88.9)$ & $99(75.6)$ \\
13 & Discussion (student-centric) & Suitable & $30(54.5)$ & $28(96.6)$ & $37(86.0)$ & $95(74.8)$ \\
\hline \multirow{2}{*}{ Theme } & suitability (average) & Suitable & 10.00 & 11.74 & 11.79 & 11.00 \\
& & Unsuitable & 3.00 & 1.26 & 1.21 & 2.00 \\
\hline
\end{tabular}

* The themes of suitability were scored from 0 to 13 points.

Table 4. Textbook Content Suitability for Elementary Students.

\begin{tabular}{|c|c|c|c|c|c|c|}
\hline Lesson & Education content & & $\begin{array}{l}\text { Elementary } \\
\text { school students }\end{array}$ & $\begin{array}{l}\text { Elementary } \\
\text { school teachers }\end{array}$ & Experts & $\begin{array}{c}\text { Total } N \\
(\%)\end{array}$ \\
\hline 1 & Concept, type, existence status, characteristics & Suitable & $44(81.5)$ & $27(84.4)$ & 42(93.3) & 113(86.3) \\
\hline 2 & $\begin{array}{l}\text { History of technical progress, important historical } \\
\text { figures }\end{array}$ & Suitable & $40(71.4)$ & $16(51.6)$ & $38(84.4)$ & 94(71.2) \\
\hline 3 & $\begin{array}{l}\text { Benefits of nuclear power generation and radiation } \\
\text { uses, probable issues when nuclear power and } \\
\text { radiation are not used }\end{array}$ & Suitable & $46(82.1)$ & $26(81.3)$ & $36(80.0)$ & 108(81.2) \\
\hline 4 & $\begin{array}{l}\text { Risk criteria, Fukushima/ Chernobyl incident, } \\
\text { radiation exposure and human disorders, damage } \\
\text { period }\end{array}$ & Suitable & $51(91.1)$ & $32(100.0)$ & $34(75.6)$ & $117(88.0)$ \\
\hline 5 & $\begin{array}{l}\text { Incident types, coping methods of students, safety } \\
\text { gear or facilities during incident }\end{array}$ & Suitable & $52(92.9)$ & $31(96.9)$ & $32(71.1)$ & 115(86.5) \\
\hline 6 & Principles of utilization, current status of utilization & Suitable & 47(83.9) & 28(87.5) & 42(95.5) & 117(88.6) \\
\hline 7 & Principles and structure of nuclear power plants & Suitable & $44(78.6)$ & $22(68.8)$ & $32(71.1)$ & 98(73.7) \\
\hline 8 & $\begin{array}{l}\text { Principles, types of utilization, and current status of } \\
\text { food irradiation }\end{array}$ & Suitable & $39(69.6)$ & 22(68.8) & $31(68.8)$ & $92(69.2)$ \\
\hline 9 & $\begin{array}{l}\text { Principles and types of medical radiation diagnosis } \\
\text { and treatments }\end{array}$ & Suitable & $48(87.3)$ & $27(84.4)$ & $32(72.7)$ & 107(81.7) \\
\hline 10 & Types of radiation irradiated products used at home & Suitable & 49(87.5) & $27(87.1)$ & $32(71.1)$ & 108(81.8) \\
\hline 11 & $\begin{array}{l}\text { Occupational clusters related to nuclear energy and } \\
\text { radiation, work performed in each occupational } \\
\text { cluster }\end{array}$ & Suitable & 41(73.2) & $27(84.4)$ & $32(71.1)$ & $100(75.2)$ \\
\hline 12 & $\begin{array}{l}\text { Transition process and current utilization status of } \\
\text { energy; types, principle, and practicality of future } \\
\text { energy }\end{array}$ & Suitable & $49(87.5)$ & 31(96.9) & $43(95.6)$ & 123(92.5) \\
\hline 13 & $\begin{array}{l}\text { Problem solving regarding radiation and nuclear } \\
\text { energy, imagination }\end{array}$ & Suitable & 47(83.9) & 28(87.5) & 40(88.9) & 115(86.5) \\
\hline \multirow{2}{*}{\multicolumn{2}{|c|}{ Learning element suitability (average) }} & Suitable & 10.75 & 11.00 & 10.41 & 10.69 \\
\hline & & Unsuitable & 2.25 & 2.00 & 2.59 & 2.31 \\
\hline
\end{tabular}

* The themes of suitability were scored from 0 to 13 points. 


\subsection{Theme Suitability for High School Students}

The themes of 13 lessons had high suitability frequency (70\%). The lowest observed frequency was $74.8 \%$ for "Group discussion about the uses of radiation and nuclear energy" (Lesson 13). Theme suitability was measured by assigning one point to each suitable lesson; the overall suitability was rated as 10.00 by the high school students, 11.74 by the high school science teachers, and 11.79 by the experts. This represents a high average suitability of 11.00 . Therefore, these themes were suitable for inclusion in the high school textbook (Table 3).

\subsection{Textbook Content Suitability for Elementary School Students}

The textbook contents of 12 lessons had high suitability frequencies (70\%). The content area "Why is radiation used for food?" (Lesson 8) had a relatively low suitability frequency (69.2\%). Content suitability was measured by assigning one point to each suitable lesson; the overall suitability was rated as 10.75 by the elementary school students, 11.00 by the elementary school science teachers, and 10.41 by the experts. This represents a high average suitability of 10.69 .

JOURNAL OF RADIATION PROTECTION AND RESEARCH, VOL.40 NO.3 SEPTEMBER 2015130
Therefore, although some revision is necessary by the textbook content of Lesson 8, the textbook contents were suitable for elementary, middle, and high school students (Table 4).

\subsection{Textbook Content Suitability for Middle School Students}

The textbook contents of 11 lessons had high suitability frequencies (>70\%). "Progress in nuclear energy research" (Lesson 11) had a content suitability rating of $68.9 \%$, but the students' rating was $73.1 \%$. The "Pro and cons in the debate on nuclear energy and radiation" (Lesson 12) had the lowest overall suitability frequency (60.5\%), but the experts' rating was relatively high (70.5\%). Content suitability was measured by assigning one point to each suitable lesson; the overall suitability was rated as 9.69 by the middle school students, 10.42 by the middle school science teachers, and 11.31 by the experts. This represents a high average suitability of 10.42. Therefore, although some revision is necessary for the textbook content of Lessons 11 and 12, the textbook contents were suitable for middle school students (Table 5).

Table 5. Textbook Content Suitability for Middle School Students.

\begin{tabular}{|c|c|c|c|c|c|c|}
\hline Lesson & Education content & & $\begin{array}{l}\text { Middle school } \\
\text { students }\end{array}$ & $\begin{array}{l}\text { Middle school } \\
\text { teachers }\end{array}$ & Experts & $\begin{array}{l}\text { Total } \mathbf{N} \\
(\%)\end{array}$ \\
\hline 1 & $\begin{array}{l}\text { Concept of atoms, concept and principles of nuclear } \\
\text { energy, characteristics of nuclear power generation }\end{array}$ & Suitable & 41(78.8) & 27(93.1) & $44(97.8)$ & 112(88.9) \\
\hline 2 & $\begin{array}{l}\text { History of technological progress, perception of nuclear } \\
\text { energy in each country }\end{array}$ & Suitable & $37(71.2)$ & $20(71.4)$ & $37(82.2)$ & $94(75.2)$ \\
\hline 3 & $\begin{array}{l}\text { Changes in energy uses, use of nuclear power plant, } \\
\text { medical radiation utilization technology }\end{array}$ & Suitable & $40(76.9)$ & 28(96.6) & 42(93.3) & $110(87.3)$ \\
\hline 4 & $\begin{array}{l}\text { Concept of radiation, characteristics by type of radiation, } \\
\text { important historical figures of radiation discovery }\end{array}$ & Suitable & $39(75.0)$ & 18(64.3) & 42(95.5) & $99(79.8)$ \\
\hline 5 & $\begin{array}{l}\text { Incident types, effect on the human body, method of re- } \\
\text { ducing exposure damages, risk levels at home and school }\end{array}$ & Suitable & $44(84.6)$ & $25(86.2)$ & 41(91.1) & $110(87.3)$ \\
\hline 6 & $\begin{array}{l}\text { Principles, types, and current status of food irradiation; } \\
\text { safety of irradiated food }\end{array}$ & Suitable & $35(67.3)$ & 18(66.7) & 39(88.6) & $92(74.8)$ \\
\hline 7 & $\begin{array}{l}\text { Types of household products using the radiation, } \\
\text { principle and current status radiation use, safety of } \\
\text { household products }\end{array}$ & Suitable & $40(76.9)$ & $24(82.8)$ & 39(90.7) & 103(83.1) \\
\hline 8 & Types of radiation in life, radiation dosage in life & Suitable & 41(78.8) & $29(100.0)$ & 42(97.7) & 112(90.3) \\
\hline 9 & $\begin{array}{l}\text { Basic principles, history, risks, damage cases, and ethical } \\
\text { values of nuclear bombs }\end{array}$ & Suitable & $35(68.6)$ & 20(69.0) & $30(71.4)$ & 85(69.7) \\
\hline 10 & $\begin{array}{l}\text { Misunderstandings and truths: investigation of urban } \\
\text { legends about fish, rain, mutation, etc. }\end{array}$ & Suitable & 40(76.9) & 23(79.3) & $36(83.7)$ & $99(79.8)$ \\
\hline 11 & $\begin{array}{l}\text { Current level of nuclear energy technology, future re- } \\
\text { search direction of nuclear energy, large-scale accelerator }\end{array}$ & Suitable & $38(73.1)$ & 18(66.7) & 28(65.1) & 84(68.9) \\
\hline 12 & $\begin{array}{l}\text { Questions regarding nuclear energy and radiation, yes and } \\
\text { no poll, persuading other people }\end{array}$ & Suitable & 25(48.1) & 19(67.9) & $31(70.5)$ & $75(60.5)$ \\
\hline 13 & $\begin{array}{l}\text { Energy depletion and sustaining period, earth environ- } \\
\text { ment and energy, nuclear fusion research (ITER), space } \\
\text { development }\end{array}$ & Suitable & $46(88.5)$ & $29(100.0)$ & $44(100.0)$ & 119(95.2) \\
\hline \multirow{2}{*}{\multicolumn{2}{|c|}{ Learning element suitability (average) }} & Suitable & 9.69 & 10.42 & 11.31 & 10.42 \\
\hline & & Unsuitable & 3.31 & 2.58 & 1.69 & 2.58 \\
\hline
\end{tabular}

* The themes of suitability were scored from 0 to 13 points. 
Table 6. Textbook Content Suitability for High School Students.

\begin{tabular}{|c|c|c|c|c|c|c|}
\hline Lesson & Education content & & $\begin{array}{l}\text { High school } \\
\text { students }\end{array}$ & $\begin{array}{l}\text { High school } \\
\text { teachers }\end{array}$ & Experts & $\begin{array}{c}\text { Total } N \\
(\%)\end{array}$ \\
\hline 1 & $\begin{array}{l}\text { First discoveries and scientists, history of incidents, history } \\
\text { of development process }\end{array}$ & Suitable & $42(75.0)$ & 26(89.7) & $41(91.1)$ & 109(83.8) \\
\hline 2 & $\begin{array}{l}\text { Definitions of nuclear energy and radiation, understanding } \\
\text { of radiation }\end{array}$ & Suitable & $53(94.6)$ & $30(100.0)$ & $42(95.5)$ & $125(96.2)$ \\
\hline 3 & $\begin{array}{l}\text { Misunderstandings and truths: investigation of urban legends } \\
\text { about fish, rain, mutation, etc. }\end{array}$ & Suitable & 47(85.5) & 26(86.7) & 39(86.7) & $112(86.2)$ \\
\hline 4 & Natural radiation, artificial radiation & Suitable & $51(91.1)$ & $30(100.0)$ & $45(100.0)$ & $126(96.2)$ \\
\hline 5 & $\begin{array}{l}\text { Principles of nuclear power generation, safety design } \\
\text { system, current status and policies, utilization status and } \\
\text { alternative energy }\end{array}$ & Suitable & $44(80.0)$ & 25(83.3) & 43(95.6) & 112(86.2) \\
\hline 6 & $\begin{array}{l}\text { Principles of irradiation of food, types and utilization } \\
\text { status, safety }\end{array}$ & Suitable & $44(78.6)$ & $24(80.0)$ & $40(88.9)$ & 108(82.4) \\
\hline 7 & $\begin{array}{l}\text { Medical radiation utilization technology, medical radiation } \\
\text { exposure amount and allowable standards, factors to } \\
\text { consider }\end{array}$ & Suitable & $49(87.5)$ & $27(90.0)$ & 42(93.3) & 118(90.1) \\
\hline 8 & $\begin{array}{l}\text { Non-destructive radiation testing, radiation gauge, neutron } \\
\text { use, environment conservation use, radioactive tracer, } \\
\text { radiation sterilization }\end{array}$ & Suitable & $42(75.0)$ & 25(83.3) & $40(88.9)$ & $107(81.7)$ \\
\hline 9 & Principles of accelerator, research areas & Suitable & $42(75.0)$ & $21(72.4)$ & $38(84.4)$ & 101(77.7) \\
\hline 10 & $\begin{array}{l}\text { Difference in perceptions of nuclear energy and radiation, } \\
\text { pro and con cases, utilization status, related occupational } \\
\text { clusters }\end{array}$ & Suitable & $45(80.4)$ & 25(83.3) & $40(88.9)$ & $110(84.0)$ \\
\hline 11 & $\begin{array}{l}\text { Incident cases (Chernobyl, Fukushima), radioactive waste, } \\
\text { descendants of atomic bomb victims }\end{array}$ & Suitable & $51(91.1)$ & 28(93.3) & $37(82.2)$ & $116(88.5)$ \\
\hline 12 & $\begin{array}{l}\text { Listening to expert opinions (food, mutation, alternative } \\
\text { energy, radiation exposure) }\end{array}$ & Suitable & $31(55.4)$ & 26(89.7) & 40(88.9) & $97(74.6)$ \\
\hline 13 & $\begin{array}{l}\text { Group discussions, yes / no poll for nuclear power } \\
\text { generation and radiation usage, value judgment }\end{array}$ & Suitable & 33(58.9) & 27(93.1) & $39(90.7)$ & $99(77.3)$ \\
\hline \multirow{2}{*}{\multicolumn{2}{|c|}{ Learning element suitability (average) }} & Suitable & 10.20 & 11.50 & 11.81 & 11.03 \\
\hline & & Unsuitable & 2.8 & 1.5 & 1.91 & 1.97 \\
\hline
\end{tabular}

* The themes of suitability were scored from 0 to 13 points.

\subsection{Textbook Content Suitability for High School Students}

The textbook contents of the 13 lessons had high suitability frequencies (>70\%). Content suitability was measured by assigning one point to each suitable lesson; the overall suitability was rated as 10.20 by the high school students, 11.50 by the high school science teachers, and 11.03 by the experts. This represents a high average suitability of 11.03 . Therefore, the textbook contents were suitable for high school students (Table 6).

\subsection{Evaluation of Textbook Contents for Elementary School Students}

With respect to the contents of the 13 lessons developed in total for the elementary school textbook, the clarity of the contents had the highest score (3.95 \pm 0.58$)$, and the interest factor had the lowest score (2.97 \pm 0.69$)$. Due to the characteristics of nuclear energy and radiation textbook, since clear content is more important than interest, we believe the full contents were acceptable. Nevertheless, cartoons, photographs, and images should be added to improve interest and understandability for elementary school students (Table 7).

\subsection{Evaluation of Textbook Contents for Middle School Students}

With respect to the contents of the 13 lessons developed for the middle school textbook, the clarity of the contents had the highest score $(4.07 \pm 0.56)$, and the easiness of the contents had the lowest score $(2.88 \pm 0.64)$. Due to the characteristics of nuclear energy and radiation textbook, since clear content is more important than easy content, we believe the full contents were acceptable. Nevertheless, cartoons, photographs, and images should be added to provide easily accessible information and improve understandability for middle school students (Table 8).

\subsection{Evaluation of Textbook Contents for High School Students}

With respect to the contents of the 13 lessons developed for the high school textbook, the clarity of the contents had the highest score $(3.76 \pm 0.46)$, and the easiness of the contents had the lowest score 


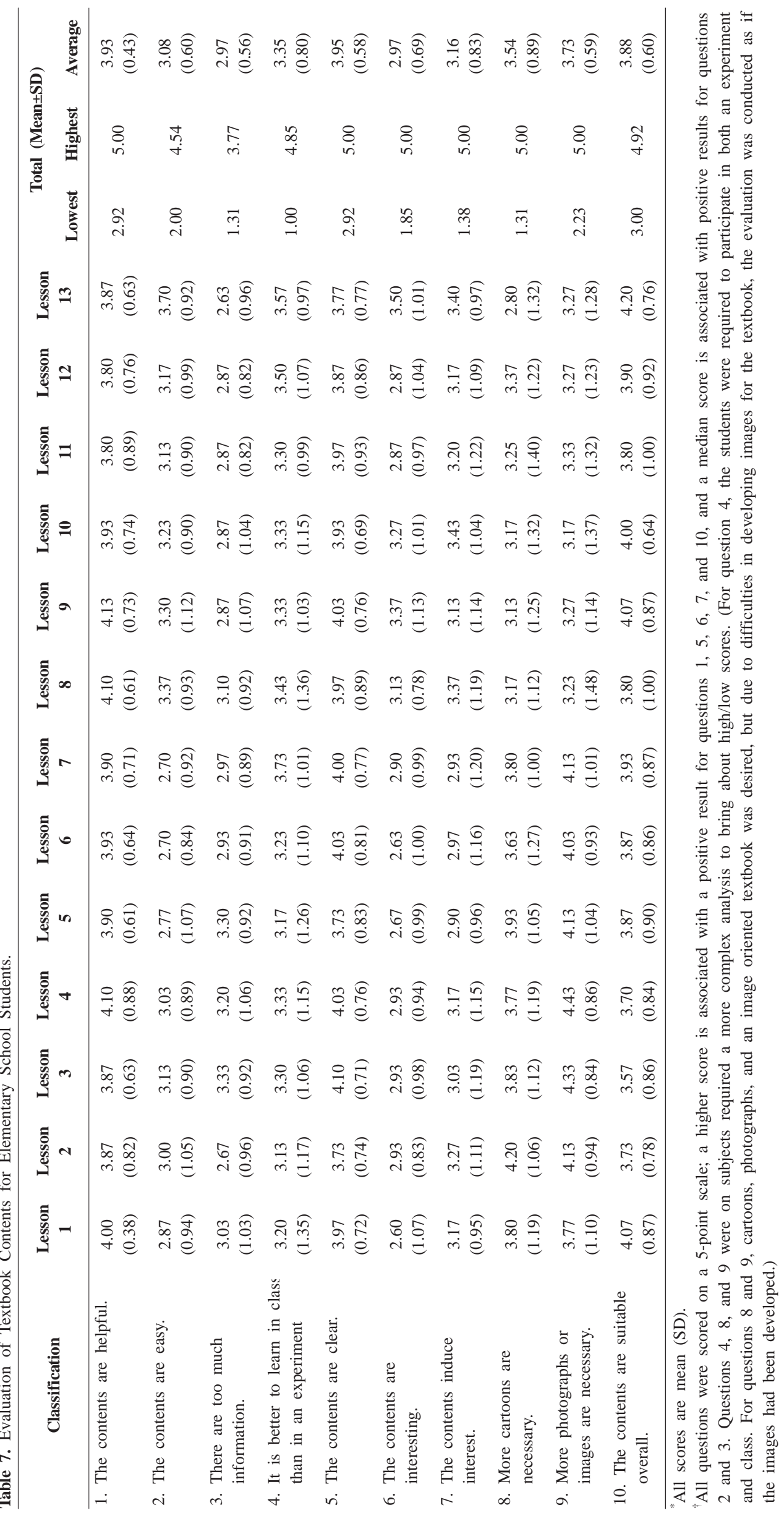




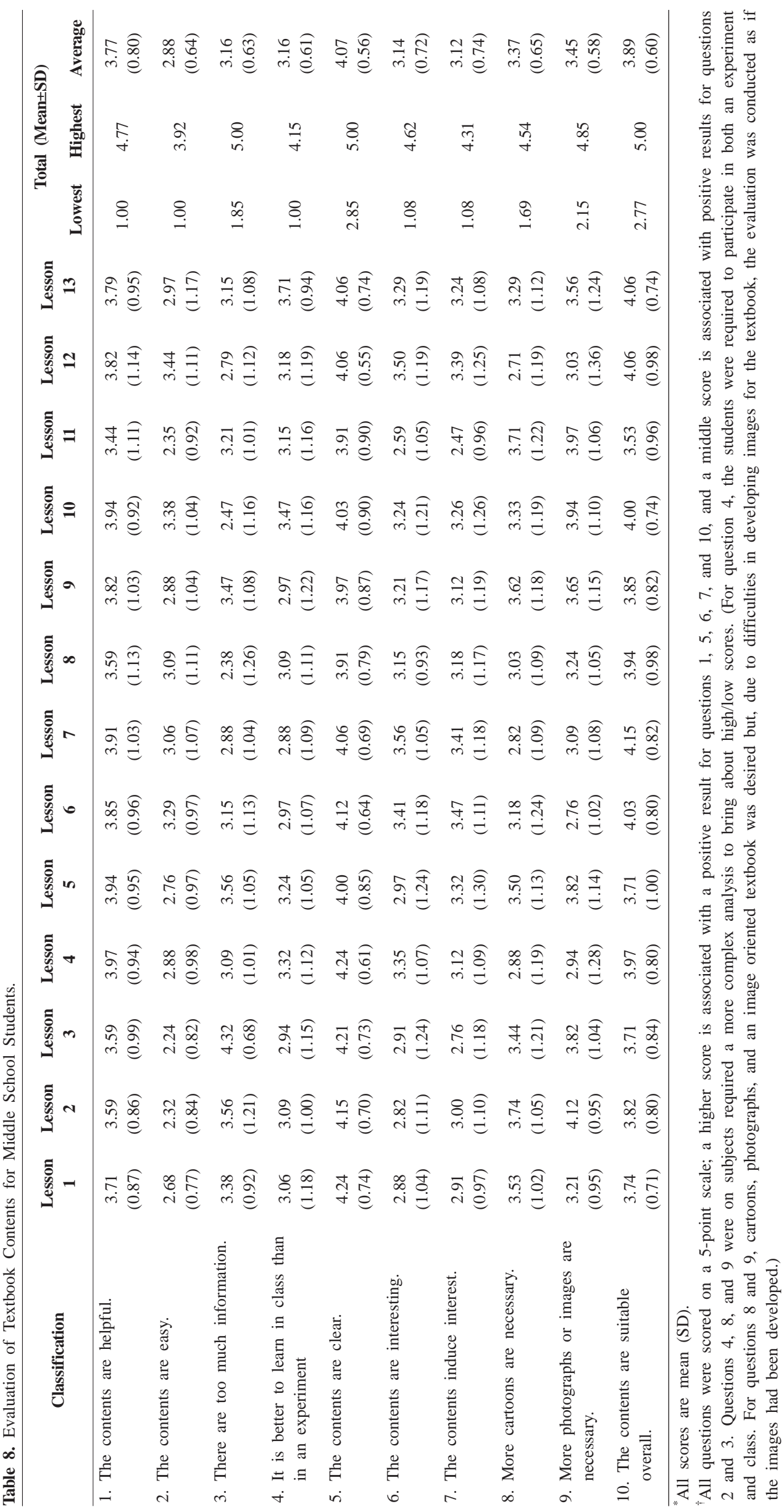




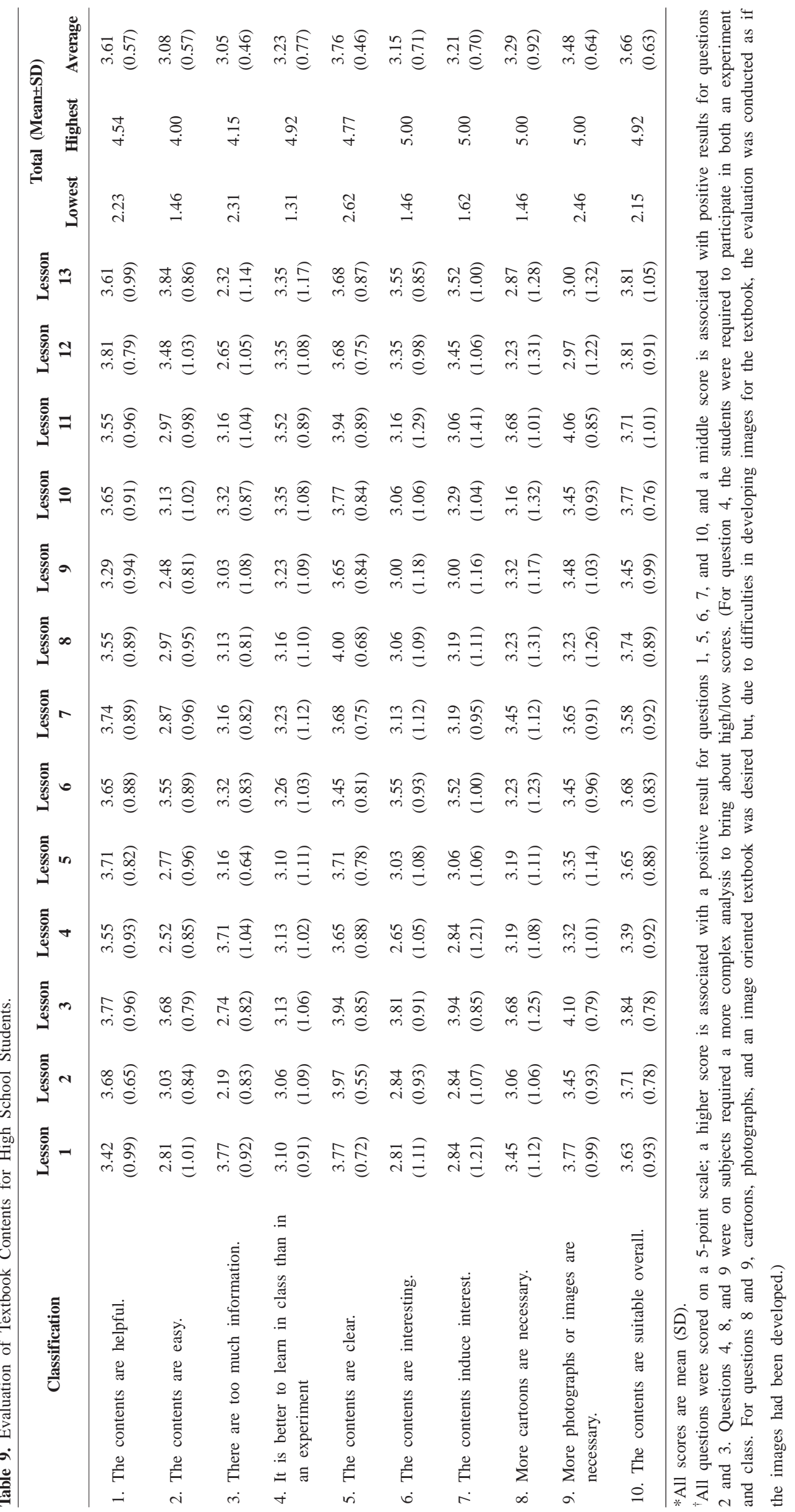


(3.08 \pm 0.57$)$. Due to the characteristics of nuclear energy and radiation textbook, since clear content is more important than easy content, we believe the full contents were acceptable. Nevertheless, cartoons, photographs, and images should be added to provide easily accessible information and improve understand ability for high school students (Table 9).

\subsection{Evaluation of Educational Effects for Textbook by School Level}

In the evaluation of the effects of textbook contents according to the educational requirements of each school level, high suitability frequencies (>80\%) were shown for "the human character," education goals, curriculum goals, evaluation method, and education time. At some levels, the high suitability frequencies (>70\%) were shown for the education grade, education type, and textbook type (Table 10). According to the research in understanding nuclear energy and radiation curriculum development conducted by Han et al (2014), "the human character" proposed for elementary and middle school students is "a person who knows and understands nuclear energy and radiation correctly” and for high school students is "a person who can make rational judgment and action for the nuclear energy and radiation" [22].

Table 10. Evaluation of Educational Effects for the Textbooks by School Level.

\begin{tabular}{|c|c|c|c|}
\hline \multirow{3}{*}{ Classification } & $\begin{array}{l}\text { Elementary school } \\
\text { students }(\mathrm{N}=37)\end{array}$ & $\begin{array}{c}\text { Middle } \\
\text { school students } \\
(\mathrm{N}=33)\end{array}$ & $\begin{array}{c}\text { High } \\
\text { school students } \\
(\mathrm{N}=74)\end{array}$ \\
\hline & Suitable & Suitable & Suitable \\
\hline & N (\%) & N (\%) & N (\%) \\
\hline Subject title & 34(91.9) & $33(100.0)$ & $55(74.3)$ \\
\hline Pursued human character & $37(100.0)$ & $33(100.0)$ & 68(91.9) \\
\hline Goal of education & 36(97.3) & $33(100.0)$ & $71(95.9)$ \\
\hline Goal of education process & 36(97.3) & $33(100.0)$ & 68(91.9) \\
\hline Goal of curriculum & 32(86.5) & 33(100.0) & 68(91.9) \\
\hline $\begin{array}{l}\text { Teaching/learning method } \\
\text { (lecture, experiment, field trip, discussion) }\end{array}$ & $35(94.6)$ & $33(100.0)$ & 72(97.3) \\
\hline $\begin{array}{l}\text { Student evaluation method } \\
\text { (presentation, discussion, report submission, etc.) }\end{array}$ & $32(86.5)$ & $28(84.8)$ & 62(83.8) \\
\hline Application of student evaluation(not reflecting grades) & 35(94.6) & 25(75.8) & $70(94.6)$ \\
\hline Education time(1 hour/week) & $31(83.8)$ & 28(84.8) & $61(82.4)$ \\
\hline Textbook type(thin textbook with many images) & 35(94.6) & 29(87.9) & $73(98.6)$ \\
\hline $\begin{array}{l}\text { Applicable school grades(elementary: } 6^{\text {th }} \text { grade, middle school: } \\
2^{\text {nd }} \text { year, high school: } 1^{\text {st }} \text { year) }\end{array}$ & 28(75.7) & 25(75.8) & 71(95.9) \\
\hline Education type(creative experience learning) & $29(78.4)$ & $32(97.0)$ & $66(89.2)$ \\
\hline
\end{tabular}

Table 11. Verification of Educational Effects by School Level.

\begin{tabular}{|c|c|c|c|c|c|c|c|}
\hline \multirow{3}{*}{ Classification } & & \multicolumn{2}{|c|}{ Elementary school } & \multicolumn{2}{|c|}{ Middle school } & \multicolumn{2}{|c|}{ High school } \\
\hline & & $\begin{array}{c}\text { Before } \\
\text { education }\end{array}$ & After education & $\begin{array}{c}\text { Before } \\
\text { education }\end{array}$ & After education & $\begin{array}{c}\text { Before } \\
\text { education }\end{array}$ & After education \\
\hline & & $\begin{array}{c}N \\
(\%)\end{array}$ & $\begin{array}{l}N \\
(\%)\end{array}$ & $\begin{array}{l}N \\
(\%)\end{array}$ & $\begin{array}{l}N \\
(\%)\end{array}$ & $\begin{array}{l}N \\
(\%)\end{array}$ & $\begin{array}{l}N \\
(\%)\end{array}$ \\
\hline \multirow{2}{*}{ Nuclear power plant } & Yes & $28(75.7)$ & 31(83.8) & 21(63.6) & $30(90.9)$ & 26(35.1) & 62(83.8) \\
\hline & No & $9(24.3)$ & $6(16.2)$ & 12(36.4) & $3(9.1)$ & 48(64.9) & 12(16.2) \\
\hline \multirow{2}{*}{ Medical radiation } & Yes & $35(94.6)$ & $37(100.0)$ & 30(90.9) & $33(100.0)$ & 67(90.5) & 73(98.6) \\
\hline & No & $2(5.4)$ & $0(0.0)$ & $3(9.1)$ & $0(0.0)$ & $7(9.5)$ & $1(1.4)$ \\
\hline \multirow{2}{*}{ Irradiated food } & Yes & 32(86.5) & 34(91.9) & 13(39.4) & 30(90.9) & 31(41.9) & 66(89.2) \\
\hline & No & $5(13.5)$ & $3(8.1)$ & 20(60.6) & $3(9.1)$ & 43(58.1) & $8(10.8)$ \\
\hline \multirow{2}{*}{$\begin{array}{l}\text { Entire nuclear power generation } \\
\text { and radiation by various fields }\end{array}$} & Yes & $36(97.3)$ & $35(94.6)$ & $24(72.7)$ & $32(97.0)$ & $56(75.7)$ & 71(95.9) \\
\hline & No & $1(2.7)$ & $2(5.4)$ & $9(27.3)$ & $1(3.0)$ & 18(24.3) & $3(4.1)$ \\
\hline Total & & $37(100.0)$ & $37(100.0)$ & $33(100.0)$ & $33(100.0)$ & 74(100.0) & 74(100.0) \\
\hline
\end{tabular}




\subsection{Verification of Educational Effects at Each School Level}

By conducting simulated classes with the textbooks, which were constructed according to the requirements of students, science teachers, and experts, the educational effects were verified by voluntary behavior changes based on value judgments. A dichotomous yes/no vote about the continued use of radiation, such as nuclear power plants, medical radiation, food irradiation, and overall usage field, yielded high frequencies of change from before to after education. In the case of elementary school students, the changes to "yes" frequencies were high after the simulated classes (Table 11). To date, the large proportion of education courses have explained the methods of teaching themes. However, reaching the goal is the objective, not the standardization of methods for reaching the goal [23]. Behavioral decision-making theory defines decision making as a psychological process of selecting an alternative with large value or an alternative with valid reason and abandoning the other alternatives by comparatively evaluating their pros and cons [24, 25]. Ajzen (1985), in the theory of reasoned action, asserts that humans act by considering the advantages and disadvantages resulting from the action through the maximum use of information gained before performing the action [26]. The information acquired from the text- books allowed students to change their value judgments. Unlike the conventional methods of providing knowledge, the receiver-oriented information themes and content led to behavior changes.

\subsection{Table of Contents in the Finalized Textbooks}

The elementary, middle, and high school students wanted to acquire information used in their daily lives, including the definition of nuclear energy and radiation, principles and status of nuclear power generation, and information about irradiated food, medical radiation, and radiation in life. The "Radiation and Life" textbook for elementary school students consists of the following chapters: Chapter 1 . What is nuclear energy and radiation?, Chapter 2. Who discovered the nuclear energy and radiation?, Chapter 3. Why is nuclear energy and radiation important?, Chapter 4. Is nuclear energy and radiation dangerous?, Chapter 5. Let's learn about what to do when an accident occurs, Chapter 6. How are nuclear energy and radiation used?, Chapter 7. What is nuclear power generation?, Chapter 8 . Why is radiation used for food?, Chapter 9. What is medical radiation?, Chapter 10. What kind of irradiated products are in our daily lives?, Chapter 11 . What jobs are related to nuclear energy and radiation?, Chapter 12 . What are energies of future?, Chapter 13. Concept of Talk-talk (a study review game).

Table 12. Contents in Finalized Textbook by School Level.

\begin{tabular}{|c|c|c|c|}
\hline $\begin{array}{l}\text { Subject } \\
\text { (Target) }\end{array}$ & $\begin{array}{c}\text { Radiation and life } \\
\text { (For elementary school students) }\end{array}$ & $\begin{array}{l}\text { Nuclear Energy and radiation } \\
\text { (For middle school students) }\end{array}$ & $\begin{array}{l}\text { Nuclear energy and radiation } \\
\text { (For high school students) }\end{array}$ \\
\hline $\begin{array}{l}\text { Table of } \\
\text { Contents }\end{array}$ & $\begin{array}{l}\text { Chapter } 1 \text {. What is nuclear energy and } \\
\text { radiation? } \\
\text { Chapter } 2 \text {. Who discovered the nuclear } \\
\text { energy and radiation? } \\
\text { Chapter 3. Why is nuclear energy and } \\
\text { radiation important? } \\
\text { Chapter } 4 \text {. Is nuclear energy and radiation } \\
\text { dangerous? } \\
\text { Chapter } 5 \text {. Let's learn about what to do } \\
\text { when an incident occurs. } \\
\text { Chapter } 6 \text {. How are nuclear energy and } \\
\text { radiation used? } \\
\text { Chapter } 7 \text {. What is the nuclear power } \\
\text { generation? } \\
\text { Chapter } 8 \text {. Why is radiation used for } \\
\text { food? } \\
\text { Chapter } 9 \text {. What is medical radiation? } \\
\text { Chapter } 10 \text {. What kind of irradiated } \\
\text { products are in our daily lives? } \\
\text { Chapter } 11 \text {. What jobs are related to } \\
\text { nuclear energy and radiation? } \\
\text { Chapter } 12 \text {. What are energies of future? } \\
\text { Chapter } 13 \text {. Concept of Talk-Talk }\end{array}$ & $\begin{array}{l}\text { Chapter 1. Nuclear energy } \\
\text { Chapter 2. Nuclear energy } \\
\text { technology } \\
\text { Chapter 3. Uses of nuclear energy } \\
\text { Chapter 4. Radiation } \\
\text { Chapter 5. Risks of radiation } \\
\text { Chapter } 6 \text {. Uses of radiation in } \\
\text { food } \\
\text { Chapter } 7 \text {. Household products } \\
\text { using radiation } \\
\text { Chapter } 8 \text {. Radiation in life } \\
\text { Chapter 9. Nuclear bombs } \\
\text { Chapter 10. Misunderstandings and } \\
\text { truths about radiation } \\
\text { Chapter } 11 \text {. Progress in nuclear } \\
\text { energy research } \\
\text { Chapter } 12 \text {. Pros and cons in the } \\
\text { debate on nuclear energy and } \\
\text { radiation } \\
\text { Chapter } 13 \text {. Energy in the future }\end{array}$ & $\begin{array}{l}\text { Chapter } 1 \text {. History of nuclear energy } \\
\text { and radiation } \\
\text { Chapter 2. Nuclear energy and radiation } \\
\text { Chapter 3. Misunderstandings and truths } \\
\text { about radiation } \\
\text { Chapter } 4 \text {. Types of radiation } \\
\text { Chapter 5. Nuclear power generation } \\
\text { Chapter } 6 \text {. Uses of radiation in food } \\
\text { Chapter } 7 \text {. Medical radiation } \\
\text { Chapter } 8 \text {. Uses of industrial radiation } \\
\text { Chapter } 9 \text {. Radiation in scientific } \\
\text { research } \\
\text { Chapter } 10 \text {. Current domestic and } \\
\text { overseas status of radiation } \\
\text { Chapter } 11 \text {. Radiation incidents and } \\
\text { radiation contamination } \\
\text { Chapter } 12 \text {. Expert opinions about the } \\
\text { use of nuclear energy and radiation } \\
\text { Chapter } 13 \text {. Group discussion about the } \\
\text { use of radiation and nuclear energy }\end{array}$ \\
\hline
\end{tabular}


The "Nuclear Energy and Radiation" textbook for middle school students consists of the following chapters: Chapter 1. Nuclear energy, Chapter 2. Nuclear energy technology, Chapter 3. Uses of nuclear energy, Chapter 4. Radiation, Chapter 5. Risks of radiation, Chapter 6. Uses of radiation in food, Chapter 7. Household products using radiation, Chapter 8. Radiation in life, Chapter 9. Nuclear bombs, Chapter 10. Misunderstanding and truths about radiation, Chapter 11. Progress in nuclear energy research, Chapter 12. Pros-cons discussion for uses of nuclear energy and radiation, Chapter 13. Energy in the future.

The "Nuclear Energy and Radiation" textbook for high school students consists of the following chapters: Chapter 1. History of nuclear energy and radiation, Chapter 2. Nuclear energy and radiation, Chapter 3. Misunderstandings and truths about radiation, Chapter 4. Types of radiation, Chapter 5. Nuclear power generation, Chapter 6. Uses of radiation in food, Chapter 7. Medical radiation, Chapter 8. Uses of industrial radiation, Chapter 9. Radiation in scientific research, Chapter 10. Current domestic and overseas status of radiation, Chapter 11. Radiation accidents and radiation contamination, Chapter 12. Expert opinions on the uses of nuclear energy and radiation (Table 12).

\section{CONCLUSION}

The textbooks for elementary, middle, and high school students were developed to help future generations make value judgments based on appropriate information about nuclear energy and radiation. The themes and educational contents of the 13 lessons, to be delivered in one semester at each school level, were selected by the educational requirements of students, science teachers, and experts. The elementary school students were interested in basic concept-oriented studying; the middle school students desired information that could be viewed from various perspectives, such as atomic bombs; and the high school students requested problem solving-oriented information.

The general trend in recent educational curriculum development suppresses national education course organizations and authorities and expands the autonomy and authority of regions and schools [27]. The derived textbook contents are expected to be helpful as first textbooks for the autonomous selection of education about nuclear energy and radiation for use in creative experiences developed at the school level. The education courses do not have significance only by being well planned; they have significance when they are executed in classes [28, 29]. The present textbooks can be used in creative experience studying. The curriculum of creative experience studying consists of four areas: autonomous activities, club activities, voluntary activities, and career activities. Specific activities of each area can be flexibly selected by a school to satisfy the characteristics of students, class, grade, school, and regional society [30].

At present, the social acceptance of nuclear energy and radiation in South Korea is a concern, and the application of educational curriculum is urgently needed to provide correct information about nuclear energy and radiation and its relationship to various areas, such as future energy, welfare, and health problems. As an example of curriculum development, the USA developed the alphabet curriculums (the PSSC and BSSC) after experiencing the so-called "Sputnik shock" caused by the USA lagging behind the Soviet Union in space development in the late 1950s. The science curriculum reformation executed gradually from 1980s led to development of national science education standard based on scientific knowledge [31]. Science education reform led to full educational curriculum reform; this demonstrates the core role of science education process in science education reform [32].

We found that the proposed textbooks were lacking sufficient cartoons, illustrations, and visual images, and the addition of these visual materials is required in the future. Because illustrations in the textbooks will be visually encoded before the text [33], these will play a very important role in the learning concept [34]. According to Girondi (1983) and Eiser et al. (1998), because the social, political, and technical factors are complex and entangled in the goals of solving energy problems, the social and political support of citizens may provide important alternative solutions [35, 36]. Before the failure of securing social acceptance due to ignorance about nuclear energy and radiation leads to biased political effects, the correct information should be provided in schools to allow future generations to develop educated value judgments. The present textbooks were developed as a part of such effort. 


\section{ACKNOWLEDGEMENTS}

This work was supported by the Ministry of Science, ICT and Future Planning.

\section{REFERENCES}

1. Cho KY, Moon JH. Investigation of perception of nuclear power by the local residents adjacent to nuclear installations. J Korean Radioact Waste Soc. 2011;9(3):181-189

2. Oh MY, Choi JY, Kim HS. Stigma effect of technology with risk: the impact of stigma on nuclear power on the perception and acceptance of products based on radiation technology. J Korean Journalism \& communication studies. 2008;52(1): 467-500.

3. Epstein S. Integration of the cognitive and the psycho-dynamic unconscious. American Psychologist. 1994;49(8): 709-724.

4. Greenberg M, Lowrie K, Burger J, Powers C, Gochfeld M, Myer H. The ultimate LULU. AM J American Planning Association, 2007;73(3): 346-352.

5. Lee HJ, Park ST. Comparison of perception differences about nuclear energy in 4 East Asian country students: aiming at 10th grade students who participated in scientific camps, from four East Asian countries: Korea, Japan, Taiwan, and Singapore. Journal of the Korean Association for Research in Science Education. 2012;32(4): 775-787.

6. Seo HJ. Fukushima nuclear accident and negative perceptions. Journal of Governmental Studies. 2013;19: 321-361.

7. Yi JH, Lee JG, Seok DH. Identification of dimensions in organizational safety climate and relationship with safety behavior. Korean Journal of Industrial and Organization Psychology. 2011; 24(3): 627-650.

8. Bird DK, Haynes K, Honert RVD, McAneney J, Poortinga W. Nuclear power in Australia: a comparative analysis of public opinion regarding climate change and the Fukushima disaster. Energy Policy. 2014;65:644-653

9. Prati G, Zani B. The Effect of the Fukushima nuclear accident on risk perception, antinuclear behavioral intentions, attitude, trust, environmental beliefs, and values. Environment and Behavior. 2012; 44(30):1-7.

10. Visschers VHM, Siegrist M. Fair play in energy policy decisions: procedural fairness, outcome fairness and acceptance of the decision to rebuild nuclear power plants. Energy Policy. 2012;46: 292-300.

11. Yamamura E. Experience of technological and natural disaster and their Impact on the perceived risk of nuclear accidents after the Fukushima nuclear disaster in Japan 2011: a cross-country analysis. The Journal of Socio-Economics. 2012; 41(4): 360-363.

12. Park ST, Choi HJ, Kim JT, Jung KJ, Lee HB, Yuk KC. The Actual status of physics teachers' perception on the concept of radiation. Journal of the Korea Association of Research in Education. 2005;25(5):603-609.

13. Kwon SH, Seo YK, Kang IK. Designing a curriculum of the media education for the higher grades in elementary school. Korean Association for Educational Information and Broadcasting. 2002;8: 29-59.

14. Slovic P. Perception of risk from radiation. Radiat Prot Dosim. 1996;68(3-4):165-180.

15. Lee SH. Strategy and process of education curriculum development. Mooneumsa, Seoul. 1994: 30-31.

16. Kwak YH. Comparative analysis of the illustrations in the Chemistry I textbooks published before and after 2009 curriculum revision. The Graduate School of Education, Inha University. 2009:1-73.

17. Kwon YM. A critical review of the policy regarding the procedure of the curriculum development at the national level from 1954 until 1997. Graduate School, Inha University. 2004;15: 1-229.

18. Hong HJ. Understanding and developing education curriculums. Mooneumsa, Seoul. 2002:307-312.

19. Ahn GD, Bae HS, Hyeon J. A study on the interests and requirements of middle and high school students in South Korea, Korean Educational Development Institute, Seoul. 1980:5.

20. Tyler RW. Basic principles of curriculum and instruction, University of Chicago Press, Chicago. 2013:1-127.

21. Taba H. Curriculum development: theory and practice. Harcourt, Brace \& World, New York, NY. 1962.

22. Han EO, Lee SK, Choi YS. Curriculum development for nuclear power and radiation education in elementary, middle, and high Schools. J Radiat 
Prot Res. 2014;39(4): 187-198.

23. Kim JS. Desirable elementary/middle/high school physics curriculums - proposal and examples: dynamics and fluctuation. Physics \& High Technology. 2005;14:41-47.

24. Simonson I, Amos T. Choice in context: tradeoff contrast and extremeness aversion. Journal of Marking Research. 1992;29:281-295.

25. Shafir E, Itamar S, Amos T. Reason-based choice. cognition. 1993;49(1-2):11-36.

26. Ajzen I. From intentions to actions: a theory of planned behavior. In J. Kuhl \& J. Beckmann (Eds.), Action Control: from Cognition to Behavior. 1985:11-39.

27. Kwon YM. A critical review of the policy regarding the procedure of the curriculum development at the national level from 1954 until 1997. Inha University. 2004:1-229.

28. Marsh CJ, Willis G. Curriculum: alternative approaches, ongoing issues. 3rd ed., Merrill Prentice Hall, Upper Saddle River, NJ. 2003.

29. Kim HB. The recent revision of the science curriculum: direction, issues, and future challenges. Education Research and Practice. 2011;77:113-132.

30. Kim AG. Operation method of creative experience activities for effective settlement of creativity and humanism education. The 33rd Education Research Papers. 2011.

31. Hurd PD. Science education for the 21st century. School Science \& Mathematics. 2000;100(6): 282-288.

32. Bybee RW. The contemporary reform of science eEducation.” In J. Photon \& R. Bowers (Eds.), Issues in Science Education, NSTA, Washington DC. 1996:1-14,

33. Kim JO. A Comparative analysis of illustrations in sensible life of the 7th education curriculum and 2007 revised curriculum. Master's Thesis, the Graduate School of Education, Gyeongin National University of Education. 2009.

34. Lee GJ. Improvement method and application model of illustrations in middle school science textbooks. Master's Thesis, Graduate School of Education, Yonsei University. 2009.

35. Girondi AJ. A Discriminate analysis of attitudes related to the nuclear power controversy. Journal of Environmental Education. 1983;14(4):2-6.

36. Eiser JR, Pligt JV. Attitude and decision. Routledge, London. 1988:150-174. 